\title{
Phosphorus Recovery from Hydrolysed Sewage Sludge Liquid Containing Metals using Donnan Dialysis
}

\author{
Ayla Uysal ${ }^{1}$, Dilara Tuncer ${ }^{1}$, Esengul Kir ${ }^{2}$, Tugba Sardohan Koseoglu ${ }^{2}$ \\ ${ }^{1}$ Suleyman Demirel University, Department of Environmental Engineering, \\ 32260 Isparta, Turkey \\ aylauysal@sdu.edu.tr; tuncerdilara@hotmail.com \\ ${ }^{2}$ Suleyman Demirel University, Department of Chemistry, \\ 32260 Isparta, Turkey \\ esengulkir@sdu.edu.tr; tugbasardohan@sdu.edu.tr
}

\begin{abstract}
Hydrolysis of phosphorus and metals from anaerobically digested sewage sludge was tested using inorganic acids $\left(\mathrm{H}_{2} \mathrm{SO}_{4}\right.$, $\mathrm{HCl}$, and $\mathrm{HNO}_{3}$ ) and organic acids (citric, oxalic, and acetic). Then, the optimize conditions for release of high phosphorus and low metals from digested sludge using $\mathrm{H}_{2} \mathrm{SO}_{4}$ by Box-Behnken design was investigated. Optimum $\mathrm{PO}_{4}-\mathrm{P}$ and metals $(\mathrm{Ca}, \mathrm{Mg}$, Na, $\mathrm{K}$, $\mathrm{Al}$, $\mathrm{Fe}$ and $\mathrm{Zn}$ ) release was obtained at $\mathrm{H}_{2} \mathrm{SO}_{4} 0.3 \mathrm{M}$, acid/sludge ratio (mL/g) 10/1 and mixing time 90 min, respectively. Donnan dialysis having a Nafion 117 cation exchange membrane was employed the selective separation of released $\mathrm{PO}_{4}-\mathrm{P}$ and metals in the hydrolysed sewage sludge liquid obtained at optimum conditions. $\mathrm{HCl}$ at different concentrations $(0.1$ and $1.0 \mathrm{M})$ were used in receiver side. High levels of metals (Ca 78.73\%, Mg 38.11\%, Na 49.43\%, K 64.62\%, Al 97.59\% and Zn 34.73\%) were passed the receiver side using $1 \mathrm{M}$ $\mathrm{HCl}$ for $24 \mathrm{~h}$. Hence, it was observed that selective separation of phosphate and metals from digested sludge using Donnan dialysis process was achieved for phosphorus recovery.
\end{abstract}

Keywords: Donnan dialysis; hydrolysed sludge; metals separation; phosphorus recovery.

\section{Introduction}

The amount of the sewage sludge is increasing due to the wide introduction of sewage systems, and most of the sewage sludge has been disposed in a landfill site as a waste [1]. However, sewage sludge represents an important secondary phosphorus source because the major percentage of the phosphate source from wastewater is transferred into the sludge. The direct agricultural usage of sewage sludge as fertiliser is increasingly restricted for soil and food safety reasons. Therefore, concepts to recover phosphorus within the wastewater treatment scheme are particularly attractive, if they promise to obtain a product which is free from contaminants and of a high quality as fertilizer [2].

To find an efficient way to release phosphorus from sewage sludge is the first step for phosphorus recovery [3]. Recently, various physical and chemical methods have been used to hydrolyse sludge [3-8]. Chemical hydrolysis is a promising method for separating elements from sewage sludge by using chemicals. Muller et al. [9] stated that sludge cells can be hydrolysed by acidic or alkali treatment at low or ambient temperatures. In the study of Weidelener et al. [10] acidic and alkaline hydrolysis were compared for three different wastewater treatment plant sludges and it is reported that the efficiency of the acidic hydrolysis was higher than the alkaline hydrolysis. However, it has been reported that chemical acidification of sewage sludge eluted heavy metals from the sludge and the elution efficiencies of heavy metals were increased with a decrease in the $\mathrm{pH}$ value of the sludge [11]. For these reasons, release of heavy metals by chemical acidification is of great importance. However, most of the investigations on acidic hydrolysis of sewage sludge were focused on the release of phosphorus, there is only a few publications investigated the release of metals. Metals may affect the quality of recovered phosphorus as clean fertiliser. But there have been few investigations which have focused on the separation of released phosphorus and metals from the acidic hydrolysis supernatant of sewage sludge. Advances in the application of ion exchange membrane processes for material separation provide new approaches. Donnan dialysis, which utilizes an ion concentration gradient across an ion selective membrane as the driving force to selectively remove ions from a feed solution, has been successfully used to concentrate or remove cations and anions from a variety of dilute waste streams. Donnan dialysis exhibits advantages over similar processes such as electrodialysis on the basis of its non- 
susceptibility to membrane fouling, ease of operation, cost effectiveness, and energy savings [12]. Also, this process is used for recovery of valuable ions and removal of undesired ions from water and wastewater [13]. However, applications of Donnan dialysis to recover ions from slurries or waste streams with high solids content are extremely limited.

This study had three goals: The first goal was investigate the characteristics of sewage sludge hydrolysis that resulted from inorganic acids $\left(\mathrm{H}_{2} \mathrm{SO}_{4}, \mathrm{HCl}\right.$, and $\left.\mathrm{HNO}_{3}\right)$ and organic acids (citric, oxalic, and acetic) at different molar concentrations. These characteristics would first be evaluated in terms of the release of phosphorus and metals. The second goal was to investigate the optimization conditions for release of high phosphorus and low metals from digested sludge using determined appropriate chemical by Box-Behnken design. The third goal was to investigate the selective separation of released phosphorus and metals in the hydrolysed liquid obtained at optimum conditions using Donnan dialysis.

\section{Materials and Methods}

\subsection{Anaerobically Digested Sewage Sludge}

The digested sewage sludge used in this study was obtained from anaerobic digester effluent of a wastewater treatment plant with an anaerobic/anoxic/aerobic (A/A/O) process located in Antalya, Turkey. The sludge samples were oven dried at $103 \pm 2{ }^{\circ} \mathrm{C}$ for $42 \mathrm{~h}$, then finely grounded and sieved to $1 \mathrm{~mm}$ mesh size. These samples were used for metals, nutrients measurements and hydrolysis experiments. The main characteristics of the anaerobically digested sewage sludge were as follows: $\mathrm{pH} 8.03$, total solid (TS) 3\%, total volatile solid (TVS) $2.90 \%$, total chemical oxygen demand (TCOD) $32800 \pm 1555.63 \mathrm{mg} / \mathrm{L}$, soluble chemical oxygen demand (SCOD) $823 \pm 26.87 \mathrm{mg} / \mathrm{L}$, total nitrogen (TN) $4.19 \%$, and total phosphorus (TP) $2.00 \%$. Metals concentrations in the anaerobically digested sewage sludge are shown in Table 1 . The digested sludge contains a high concentration of $\mathrm{Ca}, \mathrm{Mg}, \mathrm{K}, \mathrm{Na}, \mathrm{Al}, \mathrm{Fe}, \mathrm{Zn}$ and $\mathrm{Cu}$. However, the digested sludge had low concentrations of $\mathrm{Cr}, \mathrm{Pb}$ and $\mathrm{Ni}$. $\mathrm{Cd}$ and $\mathrm{Hg}$ concentrations were below the detection limit.

Table 1: Elemental composition of the anaerobically digested sewage sludge.

\begin{tabular}{|l|l|}
\hline Element & Concentration $(\mathbf{m g} / \mathbf{k g})$ \\
\hline $\mathrm{Ca}$ & $83380 \pm 112.1$ \\
\hline $\mathrm{Mg}$ & $10620 \pm 18.0$ \\
\hline $\mathrm{K}$ & $11560 \pm 19.7$ \\
\hline $\mathrm{Na}$ & $11280 \pm 21.2$ \\
\hline $\mathrm{Al}$ & $6831 \pm 10.2$ \\
\hline $\mathrm{Fe}$ & $6140 \pm 11.2$ \\
\hline $\mathrm{Zn}$ & $10960 \pm 30.5$ \\
\hline $\mathrm{Cu}$ & $9171 \pm 9.35$ \\
\hline $\mathrm{Cr}$ & $70.42 \pm 0.16$ \\
\hline $\mathrm{Pb}$ & $487.4 \pm 6.28$ \\
\hline $\mathrm{Ni}$ & $363.3 \pm 3.48$ \\
\hline $\mathrm{Cd}$ & ${ }^{\mathrm{a}}$ \\
\hline $\mathrm{Hg}$ & ${ }^{\mathrm{a}}$ \\
\hline
\end{tabular}

${ }^{\mathrm{a}}$ Below detection limit.

\subsection{Hydrolysis Experiments}

The hydrolysis with inorganic acids $\left(\mathrm{H}_{2} \mathrm{SO}_{4}, \mathrm{HCl}\right.$, and $\left.\mathrm{HNO}_{3}\right)$ and organic acids (citric, oxalic, and acetic) was performed using solutions of various concentrations $(0.1,0.5$ and $1.0 \mathrm{M})$ at a liquid $(\mathrm{ml}) / \mathrm{solid}(\mathrm{g})$ ratio of 10/1. Hydrolysis was performed using a Biosan, MSH-300i magnetic stirrer $(250 \mathrm{rpm})$ at a constant room temperature for $1 \mathrm{~h}$. In the BoxBehnken design applied, the hydrolysis with $\mathrm{H}_{2} \mathrm{SO}_{4}$ was performed with different acid concentrations and different liquid/solid ratios and different reaction times in order to find the optimum combination in terms of phosphorus and metals release. After reaction time in all hydrolysis tests, the samples were centrifuged at $8000 \mathrm{rpm}$ for 10 min to precipitate the sludge samples. The supernatant was filtered through $0.45 \mu \mathrm{m}$ membrane filter, and the concentration of phosphorus and metals in the solution was analysed. 


\subsection{Box-Behnken Design and Statistical Analysis}

Box-Behnken, a spherical and revolving design, has been applied in optimisation of chemical and physical processes because of its reasoning design and excellent outcomes. The Box-Behnken design was specifically selected since it requires fewer runs than a central composite design in cases of three or four variables.

Box-Behnken design was used to determine the effects of parameters, such as $\mathrm{H}_{2} \mathrm{SO}_{4}$ concentration (M), acid/sludge ratio $(\mathrm{mL} / \mathrm{g})$ and reaction time $(\mathrm{min})$ on phosphorus and metals release from sewage sludge by hydrolysis. Factors and levels investigated in hydrolysis tests are shown in Table 2. Three factor and three-level Box-Behnken design was used. Experimental levels used for the three factors were coded as $-1,0$ and 1.

Table 2: Factors and levels investigated in hydrolysis tests.

\begin{tabular}{|l|l|l|l|l|}
\hline \multirow{2}{*}{ Code } & \multirow{2}{*}{ Factor (Variable) } & \multicolumn{3}{|c|}{ Level } \\
\cline { 3 - 5 } & & $\mathbf{- 1}$ & $\mathbf{0}$ & $\mathbf{1}$ \\
\hline$X_{1}$ & $\mathrm{H}_{2} \mathrm{SO}_{4}$ concentration $(\mathrm{M})$ & 0.3 & 0.5 & 0.7 \\
\hline$X_{2}$ & Acid/sludge ratio $(\mathrm{mL} / \mathrm{g})$ & $5 / 1$ & $10 / 1$ & $15 / 1$ \\
\hline$X_{3}$ & Reaction time $(\mathrm{min})$ & 30 & 60 & 90 \\
\hline
\end{tabular}

Analysis of variance (ANOVA) was used to analyse the results with Minitab 16 software. MINITAB 16 software was used for regression and graphical analyses of the data. The significance of independent variables and their interactions were tested by means of ANOVA. It was considered that results with less than $95 \%$ confidence interval $(P>0.05)$ were not statistically significant for the model. According to the MINITAB 16 software, each of the response could be fitted by a predictive polynomial quadratic model, as shown in Equation (1):

$$
Y=a_{0}+a_{1} x_{1}+a_{2} x_{2}+a_{3} x_{3}+a_{12} x_{1} x_{2}+a_{13} x_{1} x_{3}+a_{23} x_{2} x_{3}+a_{11} x_{1}^{2}+a_{22} x_{2}^{2}+a_{33} x_{3}^{2}
$$

Here, $Y$ is release of phosphorus or metals $(\mathrm{mg} / \mathrm{L}) ; x_{1}, x_{2}, x_{3}$ are coded non-dimensional factors for $\mathrm{H}_{2} \mathrm{SO}_{4}$ concentration, acid/sludge ratio and reaction time, respectively; $a_{0}$ is the constant term; $a_{1}, a_{2}, a_{3}$ are linear effect terms; $a_{12}$, $a_{13}, a_{23}, a_{24}$ are interaction effect terms; and $a_{11}, a_{22}, a_{33}$ are quadric terms.

\subsection{Donnan Dialysis Experiments}

Donnan dialysis experiments were carried out using a laboratory cell consisting of two detachable compartments made of Teflon. The volume of each cell was $140 \mathrm{~mL}$ and it was mixed. Nafion 117 (DuPont) cation exchange membrane samples were treated with distilled water at $40^{\circ} \mathrm{C}$ for $1 \mathrm{~h}$, then, immerse in $1 \mathrm{M} \mathrm{HCl}$ for $1 \mathrm{~h}$, washed with distilled water and treated with $1 \mathrm{M} \mathrm{NaOH}$ for $1 \mathrm{~h}$. Membrane discs were finally immersed in $1 \mathrm{M} \mathrm{HCl}$ solution $24 \mathrm{~h}$ to transform the membrane samples to hydrogen form. The area of the exposed membrane was $23.75 \mathrm{~cm}^{2}$.

Donnan dialysis experiments were performed with the hydrolysed sludge obtained optimum conditions using $\mathrm{H}_{2} \mathrm{SO}_{4}$ by Box-Behnken design, with the hydrolysed sludge liquid $(110 \mathrm{~mL})$ placed on the feed side and $\mathrm{HCl}(0.1$ and $1 \mathrm{M}$; 110 $\mathrm{mL}$ ) on the receiver side. In the first series of experiments for $24 \mathrm{~h}, \mathrm{HCl}$ concentration in the receiver side was $0.1 \mathrm{M}$. $\mathrm{HCl}$ concentration in the receiver side was increased to $1 \mathrm{M}$ in the second series of experiments for $24 \mathrm{~h}$. In both instances, samples were collected as before at specific time intervals from both the feed and receiver sides of the Donnan cell to phosphorus and metals composition.

\subsection{Analytical Methods}

TS, TVS, TN and TP were conducted by the procedure described in the Standard Methods [14]. TCOD and SCOD were determined by the Hach reactor digestion method. $\mathrm{PO}_{4}-\mathrm{P}$ was determined using the Hach ascorbic acid method. In order to analyse total metal content, $1.0 \mathrm{~g}$ of sludge sample was weighed and applied microwave digestion using nitric acid and hydrochloric acid. $\mathrm{Ca}, \mathrm{Mg}, \mathrm{K}, \mathrm{Na}, \mathrm{Al}, \mathrm{Fe}, \mathrm{Zn}, \mathrm{Cu}, \mathrm{Cr}, \mathrm{Pb}, \mathrm{Ni}, \mathrm{Cd}$ and $\mathrm{Hg}$ were measured using inductively coupled plasma (ICPOES) (Perkin Elmer, DV2100) after acidic microwave digestion. SCOD, $\mathrm{PO}_{4}-\mathrm{P}$, and metals contents were determined by filtering the sample through $0.45 \mu \mathrm{m}$ membrane filters. The $\mathrm{pH}$ values of digested sludge were measured using 1:5 water extraction mechanically stirred for $3 \mathrm{~h}$ and subsequent determination with Hanna HI $221 \mathrm{pH}$ meter. 


\section{Result and Discussion}

\subsection{Effects of Inorganic Acids and Organic Acids on Release of Phosphorus and Metals from Digested Sludge by Hydrolysis}

Phosphorus hydrolysis is closely related to sludge $\mathrm{pH}$, especially, phosphorus is hydrolysed more rapid when $\mathrm{pH}$ decreases to 2.0 and below [15]. In Table 3, the results of the released phosphorus and metals in digested sludge using inorganic and organic acids are presented. The all acids applications were efficient for the release of phosphorus. In all hydrolysis tests, $\mathrm{Ca}, \mathrm{Mg}, \mathrm{Na}, \mathrm{K}, \mathrm{Al}, \mathrm{Fe}$ and $\mathrm{Zn}$ were released together with the phosphorus while $\mathrm{Cr}, \mathrm{Pb}, \mathrm{Cu}$ and $\mathrm{Ni}$ had a lower release. The release of phosphorus and metals increased with an increasing acids concentration.

Phosphorus recovery through struvite crystallization is technically and economically feasible [8]. Struvite crystallization is affected by the presence of metals, such as $\mathrm{Ca}, \mathrm{K}, \mathrm{Na}$, and $\mathrm{Al}$. Phosphorus can precipitate as metal phosphate by reacting with metals during the struvite crystallization [16]. In this study, $\mathrm{HCl}, \mathrm{HNO}_{3}$, citric and acetic acids applications were the efficient for releasing $\mathrm{Ca}$. Therefore, when $0.5 \mathrm{M} \mathrm{H}_{2} \mathrm{SO}_{4}$ as inorganic acid and $0.5 \mathrm{M}$ oxalic acid as organic acid were applied, release of high phosphorus and low metals were achieved. In this paper, results for optimization conditions for release of phosphorus and metals were given inorganic acid using $\mathrm{H}_{2} \mathrm{SO}_{4}$.

\subsection{Optimization of Conditions for Release of High Phosphorus and Low Metals using $\mathrm{H}_{2} \mathrm{SO}_{4}$ by $\mathrm{Box}^{-}$ Behnken design}

Box-Behnken design was employed to optimize high phosphorus and low metals release from digested sludge using $\mathrm{H}_{2} \mathrm{SO}_{4}$ by hydrolysis. Table 4 shows experimental conditions and release of phosphate and metals from digested sludge of three factors $\left(\mathrm{H}_{2} \mathrm{SO}_{4}\right.$ concentration, acid/sludge ratio and reaction time) in Box-Behnken design. The release of $\mathrm{Cr}, \mathrm{Pb}, \mathrm{Cu}$ and $\mathrm{Ni}$ in the hydrolysed liquid was not determined as they were already in trace concentrations in the hydrolysed liquid that resulted from inorganic acids and organic acids (Table 3 ).

The second-order polynomial model for the $\mathrm{PO}_{4}-\mathrm{P}$ release was regressed by considering only the significant terms, as shown in Equation (2):

$$
Y_{P}=1402,78-721,56 x_{2}+241,56 x_{2}^{2}
$$

Results showed that first-degree linear term (acid/sludge ratio $\left.\left(x_{2}\right)\right)$ and quadratic term $\left(x_{2}{ }^{2}\right)$ were more significant than the interaction effects (Equation 2). The regression model was statistically significant for release of phosphate $\left(R_{\mathrm{P}}^{2}=\right.$ 0.9511). Acid/sludge ratio had significant effects on the release of phosphate.

The regression models were statistically significant for release of $\mathrm{Mg}, \mathrm{K}, \mathrm{Al}, \mathrm{Fe}$ and $\mathrm{Zn}\left(R_{\mathrm{Mg}}^{2}=0.9727, R_{\mathrm{K}}^{2}=0.9746\right.$, $\left.R_{\mathrm{Al}}^{2}=0.8334, R_{\mathrm{Fe}}^{2}=0.8771, R_{\mathrm{Zn}}^{2}=0.8919\right) . \mathrm{H}_{2} \mathrm{SO}_{4}$ concentration had positive effect on the release of $\mathrm{Fe}, \mathrm{Zn}$ and $\mathrm{Al}$. Similarly, Zaleckas et al. [17] reported that the heavy metal extraction efficiency increased with an increasing solution concentration. On the other hand, acid/sludge ratio had negative effect on the release of Fe, $\mathrm{Zn}$ and Al. Also, acid/sludge ratio had negative effect for release of $\mathrm{Mg}$ and $\mathrm{K}$.

The composition of the sludge residue affects the hydrolysis results and thus, the recovery. The optimal situation for phosphorus recovery is to obtain a high release of phosphorus, and a low release of metals that later on can give rise to separation problems [5]. Optimum $\mathrm{PO}_{4}-\mathrm{P}$ and metals ( $\mathrm{Ca}, \mathrm{Mg}, \mathrm{Na}, \mathrm{K}, \mathrm{Al}$, Fe and $\mathrm{Zn}$ ) release was obtained at $\mathrm{H}_{2} \mathrm{SO}_{4} 0.3 \mathrm{M}$, acid/sludge ratio $(\mathrm{mL} / \mathrm{g}) 10 / 1$ and reaction time $90 \mathrm{~min}$ (test no. 7), respectively. In this test conditions, release of $\mathrm{PO}_{4}-\mathrm{P}$ was $1412.50 \mathrm{mg} / \mathrm{L}$.

\subsection{Evaluating the Selective Separation of Released Phosphorus and Metals from Hydrolysed Sludge Liquid by Donnan Dialysis}

After the acidic hydrolysis, Donnan dialysis having a Nafion 117 cation exchange membrane for $24 \mathrm{~h}$ was employed the selective separation of released $\mathrm{PO}_{4}-\mathrm{P}$ and metals in the hydrolysed sludge liquid obtained at optimum conditions using $\mathrm{H}_{2} \mathrm{SO}_{4}$. In the Donnan dialysis process, $\mathrm{H}^{+}$ions provided the driving force in the transport mechanism in which metal ions need to be separated using $\mathrm{H}^{+}$ions. Transport was driven by the $\mathrm{pH}$ differences between both sides. These $\mathrm{pH}$ changes show the exchange of $\mathrm{H}^{+}$ions with metal ions in the feed side. In this study, $\mathrm{HCl}$ solutions at different concentrations $(0.1$ and $1.0 \mathrm{M}$ ) were used in the receiver side. The separation of metals is increased with increasing the $\mathrm{HCl}$ concentration in 
the receiver side (Fig. 1). The time dependence of recovery factor (RF) values of metals in the receiver side using $1 \mathrm{M} \mathrm{HCl}$ are shown in Figure 2. Major fractions of the metals (Ca 78.73\%, Mg 38.11\%, Na 49.43\%, K 64.62\%, Al 97.59\% and Zn $34.73 \%$ ) from the hydrolysed sludge liquid were separated in the receiver side using $1 \mathrm{M} \mathrm{HCl}$ (Fig. 2). However, only $2.12 \% \mathrm{PO}_{4}-\mathrm{P}$ was removed from the feed to receiver side in this test conditions (data not shown). In this situation, it was observed that selective separation of phosphate and metals from hydrolysed sewage sludge liquid placed on the feed side using Donnan dialysis process was achieved for phosphorus recovery.

Table 3: Release of phosphorus and metals using various inorganic and organic acids ${ }^{\mathrm{a}}$.

\begin{tabular}{|c|c|c|c|c|c|c|c|c|c|c|c|c|c|}
\hline Acid & $\begin{array}{l}\text { Concentration } \\
\text { (M) }\end{array}$ & $\begin{array}{l}\mathbf{P} \\
(\mathrm{mg} / \mathrm{L})\end{array}$ & $\begin{array}{l}\mathrm{Ca} \\
(\mathrm{mg} / \mathrm{L})\end{array}$ & $\begin{array}{l}\mathrm{Mg} \\
(\mathrm{mg} / \mathrm{L})\end{array}$ & $\begin{array}{l}\mathrm{Na} \\
(\mathrm{mg} / \mathrm{L})\end{array}$ & $\begin{array}{l}\mathrm{K} \\
(\mathrm{mg} / \mathrm{L})\end{array}$ & $\begin{array}{l}\text { Al } \\
(\mathrm{mg} / \mathrm{L})\end{array}$ & $\begin{array}{l}\mathrm{Fe} \\
(\mathrm{mg} / \mathrm{L})\end{array}$ & $\begin{array}{l}\mathbf{Z n} \\
(\mathrm{mg} / \mathrm{L})\end{array}$ & $\begin{array}{l}\mathrm{Cr} \\
(\mathrm{mg} / \mathrm{L})\end{array}$ & $\begin{array}{l}\mathbf{P b} \\
(\mathrm{mg} / \mathrm{L})\end{array}$ & $\begin{array}{l}\mathrm{Cu} \\
(\mathrm{mg} / \mathrm{L})\end{array}$ & $\begin{array}{l}\mathrm{Ni} \\
(\mathrm{mg} / \mathrm{L})\end{array}$ \\
\hline \multirow{3}{*}{$\mathrm{H}_{2} \mathrm{SO}_{4}$} & 0.1 & 787.80 & 1139.00 & 453.40 & 558.30 & 522.80 & 4.55 & 13.25 & 2.90 & 0.12 & b & 0.11 & 0.34 \\
\hline & 0.5 & 1547.80 & 604.40 & 693.80 & 574.60 & 610.20 & 274.10 & 314.45 & 94.45 & 2.38 & 3.33 & 0.65 & 0.94 \\
\hline & 1 & 1667.20 & 590.90 & 682.40 & 552.20 & 587.30 & 276.45 & 320.80 & 98.60 & 2.54 & 3.18 & 3.75 & 1.40 \\
\hline \multirow{3}{*}{$\mathrm{HCl}$} & 0.1 & 370.80 & 1670.00 & 347.70 & 570.20 & 547.20 & 2.20 & 4.35 & 2.15 & 0.03 & b & 0.06 & 0.16 \\
\hline & 0.5 & 1613.20 & 8481.00 & 653.10 & 565.70 & 601.90 & 179.95 & 204.00 & 44.60 & 0.82 & 1.29 & 0.23 & 0.40 \\
\hline & 1 & 1858.20 & 9399.00 & 701.20 & 599.00 & 632.10 & 280.50 & 313.35 & 89.35 & 1.69 & 10.93 & 1.54 & 0.82 \\
\hline \multirow{3}{*}{$\mathrm{HNO}_{3}$} & 0.1 & 413.00 & 1509.00 & 324.60 & 527.20 & 492.10 & 1.85 & 3.30 & 1.30 & 0.04 & b & 0.09 & 0.20 \\
\hline & 0.5 & 1859.60 & 9900.00 & 771.60 & 662.00 & 696.00 & 191.70 & 244.25 & 55.30 & 0.99 & 1.18 & 0.10 & 0.44 \\
\hline & 1 & 1950.00 & 9707.00 & 755.20 & 622.40 & 660.90 & 298.35 & 316.25 & 97.85 & 1.14 & 6.52 & 1.26 & 0.53 \\
\hline \multirow{3}{*}{ Citric } & 0.1 & 1232.80 & 5037.00 & 470.60 & 492.10 & 477.30 & 128.10 & 99.55 & 15.50 & 0.72 & 0.45 & 0.16 & 0.36 \\
\hline & 0.5 & 1675.00 & 8225.00 & 563.00 & 514.90 & 518.90 & 199.65 & 225.20 & 28.70 & 1.34 & 0.18 & 0.13 & 0.37 \\
\hline & 1 & 1931.60 & 9640.00 & 652.50 & 589.50 & 606.30 & 241.85 & 275.80 & 38.65 & 1.35 & 1.93 & 0.12 & 0.38 \\
\hline \multirow{3}{*}{ Acetic } & 0.1 & 419.20 & 1113.00 & 318.70 & 496.50 & 449.50 & 0.80 & 2.70 & 1.50 & 0.06 & b & 0.13 & 0.39 \\
\hline & 0.5 & 954.60 & 4619.00 & 546.60 & 588.60 & 543.90 & 2.85 & 12.30 & 4.75 & 0.16 & $\mathrm{~b}$ & 0.08 & 0.46 \\
\hline & 1 & 1201.20 & 6960.00 & 664.10 & 667.30 & 632.10 & 5.45 & 32.80 & 11.75 & 0.30 & $\mathrm{~b}$ & 0.18 & 0.66 \\
\hline \multirow{3}{*}{ Oxalic } & 0.1 & 869.40 & 170.40 & 285.00 & 459.40 & 404.40 & 4.20 & 7.20 & 2.20 & 0.16 & b & 0.14 & 0.39 \\
\hline & 0.5 & 1628.40 & 7.09 & 635.30 & 500.10 & 538.80 & 214.15 & 241.05 & 29.60 & 1.47 & $\mathrm{~b}$ & $\mathrm{~b}$ & 0.35 \\
\hline & 1 & 1596.60 & 14.04 & 603.30 & 492.00 & 76.56 & 219.30 & 247.90 & 25.75 & 2.50 & b & 0.08 & 0.51 \\
\hline
\end{tabular}

${ }^{a}$ Release of phosphorus and metals depicts the mean concentrations of the duplicate analysis.

${ }^{\mathrm{b}}$ Below detection limit.
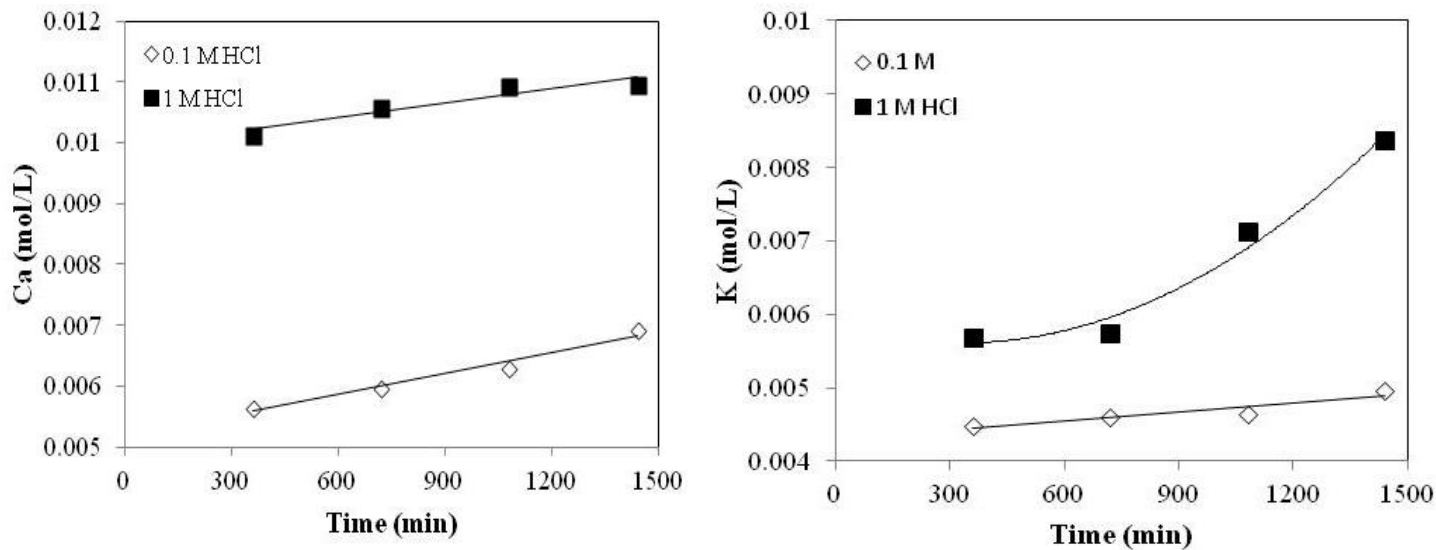

Fig. 1: Receiver side concentrations of $\mathrm{Ca}$ and $\mathrm{K}$ as a function of time. 
Table 4: Release of phosphate and metals from digested sludge using $\mathrm{H}_{2} \mathrm{SO}_{4}$ by Box-Behnken design ${ }^{\mathrm{a}}$.

\begin{tabular}{|c|c|c|c|c|c|c|c|c|c|c|c|}
\hline Test No & $\begin{array}{l}X_{1} \\
\left(\mathrm{H}_{2} \mathrm{SO}_{4},\right. \\
\mathrm{M})\end{array}$ & $\begin{array}{l}X_{2} \\
\text { (Acid/sludge } \\
\text { ratio, } \mathrm{mL} / \mathrm{g} \text { ) }\end{array}$ & $\begin{array}{l}X_{3} \\
\text { (Reaction } \\
\text { time, min) }\end{array}$ & $\begin{array}{l}\mathrm{PO}_{4} \text {-P } \\
\text { Release } \\
(\mathrm{mg} / \mathrm{L})\end{array}$ & \begin{tabular}{|l} 
Ca \\
Release \\
$(\mathbf{m g} / \mathbf{L})$
\end{tabular} & $\begin{array}{l}\text { Mg } \\
\text { Release } \\
\text { (mg/L) }\end{array}$ & $\begin{array}{l}\text { Na } \\
\text { Release } \\
(\mathrm{mg} / \mathrm{L})\end{array}$ & $\begin{array}{l}\text { K } \\
\text { Release } \\
(\mathrm{mg} / \mathrm{L})\end{array}$ & $\begin{array}{l}\text { Al } \\
\text { Release } \\
(\mathrm{mg} / \mathrm{L})\end{array}$ & $\begin{array}{l}\text { Fe } \\
\text { Release } \\
(\mathrm{mg} / \mathrm{L})\end{array}$ & $\begin{array}{l}\text { Zn } \\
\text { Release } \\
\text { (mg/L) }\end{array}$ \\
\hline 1 & 0.3 & $5 / 1$ & 60 & 1933.33 & 1393.00 & 990.20 & 1024.00 & 890.70 & 12.89 & 75.61 & 17.44 \\
\hline 2 & 0.7 & $5 / 1$ & 60 & 2175.00 & 513.60 & 1293.00 & 1008.00 & 1021.00 & 518.70 & 678.20 & 168.90 \\
\hline 3 & 0.3 & $15 / 1$ & 60 & 924.07 & 583.30 & 462.10 & 372.90 & 388.60 & 188.90 & 238.60 & 61.84 \\
\hline 4 & 0.7 & $15 / 1$ & 60 & 950.00 & 631.50 & 439.20 & 349.50 & 361.10 & 194.50 & 266.60 & 67.53 \\
\hline 5 & 0.3 & $10 / 1$ & 30 & 1345.83 & 707.80 & 680.10 & 588.90 & 622.50 & 247.70 & 291.20 & 68.81 \\
\hline 6 & 0.7 & $10 / 1$ & 30 & 1410.42 & 617.00 & 652.50 & 528.20 & 571.10 & 281.10 & 379.30 & 95.01 \\
\hline 7 & 0.3 & $10 / 1$ & 90 & 1412.50 & 548.90 & 696.60 & 560.10 & 575.90 & 248.40 & 326.80 & 81.53 \\
\hline 8 & 0.7 & $10 / 1$ & 90 & 1422.92 & 589.20 & 697.00 & 527.90 & 547.90 & 300.00 & 415.50 & 104.8 \\
\hline 9 & 0.5 & $5 / 1$ & 30 & 2466.67 & 550.60 & 1302.00 & 1060.00 & 1042.00 & 398.10 & 503.10 & 114.5 \\
\hline 10 & 0,5 & $15 / 1$ & 30 & 872.92 & 672.30 & 468.00 & 365.50 & 375.40 & 192.70 & 256.40 & 64.42 \\
\hline 11 & 0.5 & $5 / 1$ & 90 & 2894.44 & 645.80 & 1501.00 & 1209.00 & 1203.00 & 439.20 & 619.10 & 148.9 \\
\hline 12 & 0.5 & $15 / 1$ & 90 & 950.00 & 704.60 & 501.70 & 385.70 & 402.30 & 213.20 & 291.70 & 76.52 \\
\hline 13 & 0.5 & $10 / 1$ & 60 & 1408.33 & 670.80 & 718.10 & 570.60 & 593.00 & 297.30 & 410.80 & 105.50 \\
\hline 14 & 0.5 & $10 / 1$ & 60 & 1412.50 & 616.30 & 758.90 & 591.30 & 618.70 & 319.90 & 435.00 & 114.60 \\
\hline 15 & 0.5 & $10 / 1$ & 60 & 1387.50 & 603.40 & 722.90 & 563.40 & 584.10 & 298.90 & 415.10 & 107.40 \\
\hline
\end{tabular}

${ }^{a}$ Release of phosphate and metals depicts the mean concentrations of the duplicate analysis.

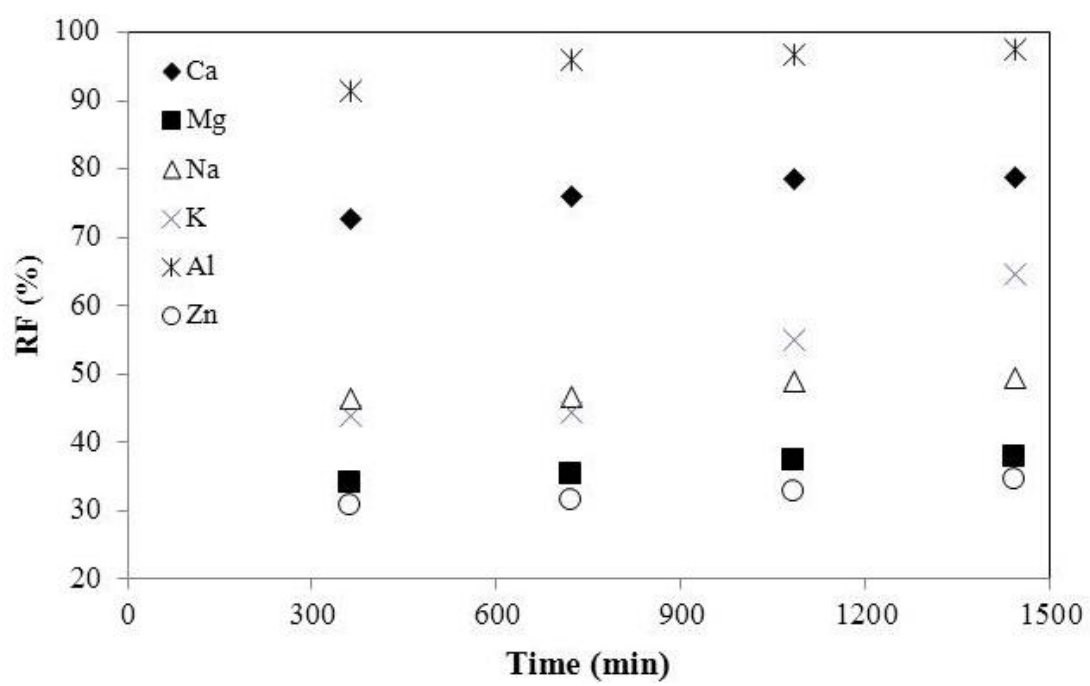

Fig. 2: RF values of metals in the receiver side as a function of time.

\section{Conclusion}

In the hydrolysis process, acid/sludge ratio had significant effects on the release of phosphate from digested sludge. $\mathrm{Ca}, \mathrm{Mg}, \mathrm{Na}, \mathrm{K}, \mathrm{Al}, \mathrm{Fe}$ and $\mathrm{Zn}$ were hydrolysed as well as phosphate. Increasing the $\mathrm{HCl}$ concentration from 0.1 to $1 \mathrm{M}$ in the Donnan dialysis process, separation of metals from feed side to receiver side increased. High levels of metals $(\mathrm{Ca}$ 78.73\%, $\mathrm{Mg} 38.11 \%, \mathrm{Na} 49.43 \%, \mathrm{~K} 64.62 \%, \mathrm{Al} 97.59 \%$ and $\mathrm{Zn} \mathrm{34.73 \% )} \mathrm{were} \mathrm{passed} \mathrm{the} \mathrm{receiver} \mathrm{phase} \mathrm{using} 1 \mathrm{M} \mathrm{HCl}$. $\mathrm{Ca}, \mathrm{K}, \mathrm{Al}$, and $\mathrm{Na}$ ions were effectively separated by using Donnan dialysis to prevent re-precipitation of the phosphorus in the recovery process. However, only $2.12 \% \mathrm{PO}_{4}-\mathrm{P}$ was removed from the feed to receiver side. It was concluded that 
recovery of phosphorus using acid hydrolysis and Donnan dialysis should be feasible due to remove metals effectively without phosphorus loss from anaerobically digested sewage sludge.

\section{Acknowledgements} YL2-14).

This study was supported by Research Project Funding Unit of the Suleyman Demirel University (project no. 4143-

\section{References}

[1] M. Takahashi, Y. Takemoto, and K. Onishi, "Phosphorus recovery from carbonized sewage sludge by hydrothermal processes," J. Mater. Sci. Eng., vol. 5, pp. 58-62, 2015.

[2] C. Blöcher, C. Niewersch, and T. Melin, "Phosphorus recovery from sewage sludge with a hybrid process of low pressure wet oxidation and nanofiltration," Water Res., vol. 46, pp. 2009-2019, 2012.

[3] W. Bi, Y. Li, and Y. Hu, "Recovery of phosphorus and nitrogen from alkaline hydrolysis supernatant of excess sludge by magnesium ammonium phosphate," Bioresour. Technol., vol. 166, pp. 1-8, 2014.

[4] Y. Chen, S. Jiang, H. Yuan, Q. Zhou, and G. Gu, "Hydrolysis and acidification of waste activated sludge at different pHs," Water Res., vol. 41, pp. 683-689, 2007.

[5] K. Stark, E. Plaza, and B. Hultman, "Phosphorus release from ash, dried sludge and sludge residue from supercritical water oxidation by acid or base," Chemosphere, vol. 62, pp. 827-832, 2006.

[6] A. Sano, M. Kanomata, H. Inoue, N. Sugiura, K. Q. Xu, and Y. Inamori, "Extraction of raw sewage sludge containing iron phosphate for phosphorus recovery," Chemosphere, vol. 89, pp. 1243-1247, 2012.

[7] N. Takiguchi, M. Kishino, A. Kuroda, J. Kato, and H. Ohtake, "Effect of mineral elements on phosphorus release from heated sewage sludge," Bioresour. Technol., vol. 98, pp. 2533-2537, 2007.

[8] Y. Wang, Q. Xiao, H. Zhong, X. Zheng, and Y. Wei, "Effect of organic matter on phosphorus recovery from sewage sludge subjected to microwave hybrid pretreatment," J. Environ. Sci., vol. 39, pp. 29-36, 2016.

[9] J. A. Muller, A. Winter, and G. Stunkmann, "Investigation and assessment of sludge pretreatment processes," Water Sci. Technol., vol. 49, pp. 97-104, 2004.

[10] A. Weidelener, K. Brechtel, W. Maier, J. Krampe, and U. Rott, "Recovery of phosphorus from sewage sludge as MAP," in IWA/WISA Conference on the Management of Residues Emanating from Water and Wastewater Treatment, pp. 9-12 August, Johannesburg, South Africa, 2005.

[11] A. Ito, K. Takahashi, J. Aizawa, and T. Umita, "Enhanced heavy metals removal without phosphorus loss from anaerobically digested sewage sludge," Water Sci. Technol., vol. 58, pp. 201-206, 2008.

[12] Q. Wang, J. J. Lenhart, and H.W. Walker, "Recovery of metal cations from lime softening sludge using Donnan dialysis," J. Membrane Sci., vol. 360, pp. 469-475, 2010.

[13] E. Kir, B. Gurler, and A. Gulec, "Boron removal from aqueous solution by using plasma-modified and unmodified anion-exchange membranes," Desalination, vol. 267, pp. 114-117, 2011.

[14] APHA, AWWA, and WEF, Standard Methods for the Examination of Water and Wastewater. 21st Ed., Washington, DC, 2005.

[15] Z. Tan and A. Lagerkvist, "Phosphorus recovery from the biomass ash: a review," Renew. Sust. Energy Rev., vol. 15, pp. 3588-3602, 2011.

[16] Y. Jaffer, T. A. Clark, P. Pearce, and S.A. Parsons, "Potential Phosphorus Recovery by Struvite Formation," Water Res., vol. 36, pp. 1834-1842, 2002.

[17] E. Zaleckas, V. Paulauskas, and E. Sendzikiene, "Fractionation of heavy metals in sewage sludge and their removal using low-molecular-weight organic acids," J. Environ. Eng. Landsc., vol. 21, pp. 189-198, 2013. 